\title{
African traditional widowhood rites and their benefits and/or detrimental effects on widows in a context of African Christianity
}

\author{
Author: \\ Matsobane Manala ${ }^{1}$ \\ Affiliation: \\ ${ }^{1}$ Department of Philosophy, \\ Practical and Systematic \\ Theology, University of South \\ Africa, South Africa \\ Correspondence to: \\ Matsobane Manala \\ Email: \\ manalmj@unisa.ac.za \\ Postal address: \\ PO Box 392, University of \\ South Africa, Pretoria 0003, \\ South Africa \\ Dates: \\ Received: 17 Feb. 2015 \\ Accepted: 22 Apr. 2015 \\ Published: 07 Oct. 2015 \\ How to cite this article: \\ Manala, M.J., 2015, 'African \\ traditional widowhood \\ rites and their benefits \\ and/or detrimental effects \\ on widows in a context \\ of African Christianity', \\ HTS Teologiese Studies/ \\ Theological Studies 71(3), \\ Art. \#2913, 9 pages. http:// \\ dx.doi.org/10.4102/hts. \\ v71i3.2913

\section{Copyright:} \\ C 2015. The Authors. \\ Licensee: AOSIS \\ OpenJournals. This work is \\ licensed under the Creative \\ Commons Attribution \\ License.
}

Read online:

Scan this QR
code with your
smart phone or
mobile device
to read online.

Traditional Africans teach $u b u n t u$ principles of communality, mutual respect, caring and so forth, but they do not walk the talk with regard to the treatment of widows. In the footsteps of Jesus of Nazareth, Christian communities preach unconditional love, especially for the poor, marginalised and vulnerable. Implementation is, however, grossly lacking in respect of the treatment of widows. There is thus an apparent deliberate uncaring, disrespectful, discriminatory, impolite and unjust treatment of widows in African communities in spite of the $u b u n t u$ values and Christian teaching that emphasise love and caring, especially towards the grieving and thus vulnerable widows. Widows seem to be neglected and even oppressed in our time. The aim of this research is to critically examine African traditional widowhood rites and practices with special reference to the comfort or pain to which they subject African widows. The research further aims to examine the behaviour of some African Christians belonging to three congregations of one mainline church to determine whether their treatment of widows resonates with Jesus' teaching regarding the requisite care of widows. The issue of widowhood in Africa, in terms of the apparent plight of these bereaved and grieving women, needs to be urgently addressed for change in the 21st century. A critical literature study of relevant sources and a newspaper article will be used for this research. My personal experiences and continuing observation as an insider will also inform the research in useful ways.

\section{Introduction}

The challenge presented by the neglect and maltreatment of widows does not receive sufficient attention as contemporary scholarship seems reluctant to reflect on African widowhood rites and their consequences. Limann (2003:1), Owen (2001:10; 2011:616), Potash (1968:1) and United Nations (1995, cited in Sossou 2002:201) decry the lack of scholarly research on global and African widowhood rites and practices despite the fact that widows make up a large part of the female population in all societies. These rites and practices therefore remain unexposed, unchallenged and not sufficiently reflected upon in spite of the pain they inflict on the widows. Owen (2001:10) rightly asserts in this regard: 'Research into the nature and effect of widows' mourning rites has been scant although the practice violates many basic principles contained in all key international human rights conventions.' African authors know about the supposed innate compassion of Africans that manifests in strong kinship and mutual caring. This compassion is underpinned by the ubuntu philosophy. Accordingly, Masango (2006:930) states: 'The enjoyment of life is part of living as much as ubuntu is part of humanity.' One then cannot but direct the following question to Africans in the face of this seeming nonchalance by authors and communities: What has become of the call of ubuntu amongst Africans today?

The dearth of literature on this important and relevant topic in theology and particularly practical theology is cause for grave concern. To my mind, it signifies a neglect of the widows' wellbeing by Christians. One can then ask the same question of Christians: What has become of this divinely demanded compassion for widows amongst today's Christians, given this seeming neglect?

This article aims to examine critically a few African widowhood rites and practices and their perceived benefits and disadvantages from the perspective of African widows as articulated in some relevant studies on the subject. Though African cultures are diverse, there are many commonalities with regard to widowhood rites and practices. This is clearly stated in literature. For example, Kotzé, Lishje and Rajuili-Masilo (2012:744) point out that the widows they interviewed claimed diverse cultural identities but that ' $[d]$ espite their different cultural affiliations, the women's experiences of mourning practices in their communities share a number of similarities' (see also Nowye 2005:147). Manyedi, Koen and Greeff $(2003: 78,79)$ also point 
out that their findings were confirmed by other authors such as Pauw, Fude and De Gamo and Kitson, who worked in different African contexts. This is an indication that there are many commonalities amongst many African communities with regard to widowhood rites and practices. It is for this reason that I utilise information from different African contexts in my critical literature study.

The hope is, in the end, to point to a possible corrective intervention leading to a normative situation which is one of the four tasks of practical theology. In this regard, Osmer (2008:11) identified the descriptive empirical, the interpretive, the pragmatic and the normative tasks of practical theology. My personal experiences and events involving my church congregants as well as an article in a daily newspaper are used to highlight and describe the plight of widows in African contexts. Ubuntu philosophy and practice as well as Christian teaching on the subject are used to critique the treatment of widows in Africa. This is followed by a brief literature study. Creswell (2003) claims the following with regard to the value of a literature review:

1) It shares with the reader the results of other studies that are closely related to the study being reported; 2 ) it relates a study to the larger ongoing dialogue in the literature about a topic, filling the gaps and extending prior studies and 3) it provides a framework for establishing the importance of [your] study as well as benchmark for comparing the results of a study with other findings. (pp. 29-30)

Many of the sources examined point to the pain and stress to which African widowhood rites and practices subject African widows, and only an insignificant minority of the sources defends the shabby treatment of widows embedded in traditional African widowhood rites. The following are a few African widowhood rites and practices in a few African contexts.

\section{Some African widowhood rites in the Phokwane area}

This section describes some of the widowhood rites in the Phokwane area of Limpopo. The description is based on research conducted by Pauw, published in 1990, and confirmed by other researchers in some other African contexts. Most of these rites are meant to cleanse the widow of perceived defilement related to the death of her husband and to neutralise and/or counter the effects of ritual danger embedded in widowhood. Of course, this brief description is not exhaustive. Other African widowhood rites are interspersed throughout this article.

\section{Hands and feet sprinkled with water treated with leilane and head shave}

Immediately after a burial, the widow participates in a general washing of the hands, and the feet and the grave is sprinkled with water treated with leilane (Pelargonium sp.), which is a plant used extensively to neutralise the effect of ritual danger (Pauw 1990:79). This is done to ensure that the widow together with other family members do not constitute a ritual danger to the community.

This ritual is followed by shaving the head of the widow, a rite in which the widow participates with other family members (see also Baloyi \& Makobe-Rabothata n.d.:236). The practice of head shaving is almost the same amongst many other peoples of Africa, for instance the Igbo of Nigeria, the Zulus of South Africa (both in rural KwaZulu-Natal and urban Soweto), as well as the Bapedi of Phokwane and many other villages (see Nowye 2005:152; Pauw 1990:79; Rosenblatt \& Nkosi 2007:78). This practice is also performed in my home village of Bakenberg in Mokopane.

\section{Blackening of the widow's body and attire}

The widow's body and traditional garb, consisting of the back and front skin aprons which are normally white in colour, are blackened with a mixture of fat, earth and the baked or scorched kernel of the motšhidi (Ximenia caffra) fruit whilst the tips of her double-pointed back apron are cut off. The widow is also given a black head cloth and dress, and wears a special headband made of python skin (for a woman of mošate) or cow skin (for common women), all of which are referred to as clothes of darkness (sefifi or senyama) (Pauw 1990). In many contemporary African villages in South Africa, the widow is '... required to wear black clothes ... and behave in a manner that shows that she is grieving' (Kotzé et al. 2012:754). She also has to give way to other road or path users whom she meets when walking in the road or path. Kotzé et al. (2012) mention the following:

The widow wearing black clothes also has to sit at the back of a bus or taxi so as not to expose other travellers to her back and the possibility of a 'bad omen or bad luck'. (p. 755)

I observed this also with widows in the three congregations in three Pretoria townships which I served in my 35 years of ministry. In these cases, I saw widows sitting at the back pew during the worship service. They were totally isolated from other worshippers who were sitting some distance from them. The mourning period is usually a year but can be six months, depending on the mourning requirements of the different communities. In some African villages such as my home village, Bakenberg, the mourning period may be interrupted by the approaching rain season during which period the king gives the order to have all widows in the village take off their mourning clothes in order to not inhibit a good rainfall. This means that some widows may mourn their husbands for a shorter period as a result of this need to have the possible obstruction to good rain, removed.

In many African traditions, compliance with the mourning rites and practices is a sign '... that a widow is grieving properly and that she respects her deceased husband' (Kotzé et al. 2012:754; Rosenblatt \& Nkosi 2007:67). All these, together with other symbols, are regarded as the symbols of the sorrow that a bereaved widow is expected to display. For the first few weeks, widows in the Phokwane 
area have to wear their clothes inside out and eat with her left hand from a lid (Pauw 1990:79). The widow is thus rendered abnormal. It is not clear how eating with the left hand from a lid and wearing clothes inside out protect both the widow and the community from defilement. It seems that practices like these are simply meant to demean the widow. The widow is also expected to stay at home during the mourning period, a practice which can be problematic to today's working women.

\section{Prohibition from leaving her home}

Baloyi and Makobe-Rabothata (n.d.) state the following:

In South Africa some of the Bapedi tribe[s] that originate from Limpopo province believe that when a married man dies, his widow is forbidden from arriving home after sunset, visiting neighbors, attending family and community functions. (p. 236)

This is said to help protect the widow against suspicions of witchcraft as Rosenblatt and Nkosi (2007:78) state: 'For the widow in inzila [mourning], a danger is that if something happens to someone in the community, for example, if a child dies, she might be blamed' (translation in square brackets added - MM). The widow is confined to her home, a tradition which is experienced by some widows as imprisonment. Manyedi et al. (2003:78) report this in the words of a widow: 'I must just stay home; it means I am in prison. I am not supposed to visit any house and I cannot talk to people for several weeks.' This prohibition is lifted after several weeks (Pauw 1990). However, even then, before she can visit other people's homes, she must first be ceremonially cleansed. Accordingly, a companion announces her arrival to inhabitants of the home so that they can provide grains of indigenous sorghum (mabele) or maize on which the widow blows before scattering it around inside the house and in the yard. The aim of this act is to protect other people and lands or fields from the ritual danger or defilement that can, according to belief, result in a plague of mice that damages property at the affected people's homes (Pauw 1990:80). In some communities like my own at Bakenberg in Mokopane, the widow is not even allowed to greet people first. She must wait for others to greet her.

The rules become stricter when the widow has to visit the lands or fields. She must first undergo ritual washing with rain medicine which is controlled by the king. For her to gain access to the king's headquarters accompanied by another widow who has completed her mourning period, she has to have the sorghum-beer ritual performed for her. From there, she will be taken to the lešaka la pula [rain kraal] where the ritual is supervised by a female official of the queen mother. Lešaka la pula comprises two small linked enclosures at the back of the queen mother's lapa (Pauw 1990). Rain medicine from the pots in the second enclosure is poured into a hollow in a grinding stone in the first enclosure, and into this fluid, blood is allowed to drop from cuts between the widow's thumb and forefinger, and her big and second toe. She washes her hands and feet with the mixture and pours it back into the rain pots. She is then given some rain medicine to sprinkle by the roadside and around her own land when she leaves the residential area. This is to neutralise any adverse influence she may have on rain (Pauw 1990:80). Even after this purification, she still has to respect the rule of not spending the night outside of the residential area (Baloyi \& Makobe-Rabothata n.d.:236; Pauw 1990:80). The question is then: What are the benefits and disadvantages in the African traditional widowhood rites.

\section{Perceived benefits of African widowhood rites and practices}

This section examines the literary evidence for the perceived benefits of widowhood rites and practices for widows and their families. One positive effect mentioned by Makatu, Wagner and Ruane (2008:573) is healing: 'Since death has a negative impact on the remaining persons' lives, rituals are considered to have therapeutic value that assists the griever in moving on with her life.' This is confirmed by Nowye (2005:153), citing Rosenblatt who suggested that '... prescriptions through customs may be more effective than prescriptions for individual cases who [sic] happen to encounter professional advice'. Nowye (2005) provides the following definition of African grief work that confirms the healing ability of traditional African widowhood rites:

African grief work can be defined as the patterned ways invented in traditional communities for the successful healing of the psychological wounds and pain of bereaved persons. It is a healing system grounded in 'ecologically sound rituals and ceremonies that facilitate experiential healing'. (Sisoda 1997) Its target clients are any members of the community burdened by painful loss of a loved one. (p. 148)

Some mourning rites are said to also have the aim of removing the bad luck or misfortune or senyama that is said to surround the widow and which makes people discriminate against her or fear her. I concede that, if the widow knows that the purpose of the traditional widowhood rites is to remove the alleged bad luck or senyama, it can be therapeutic. As such, it can be experienced by the widow as facilitating her integration with the community, which she desperately longs for.

Tasie (2013:155-162) also points to the positive value of widowhood rites amongst his people. In his study, he (Tasie 2013) argues as follows:

... widowhood rites in Africa were not primarily designed to de-womanise African womanhood, or impoverish and oppress women; nor are they part of the so-called male chauvinism. Rather, the widowhood rites are generally intended for the overall good of the widow. (p. 156)

He (Tasie 2013) sums up the purpose of the Isiokpo tribe's widowhood rites in two main categories, namely:

1) First, to sever the ties between a dead husband and his living wife. For, the Isiokpo believe that at the immediate aftermath of death, the ghost spirit lurk (sic) around the homestead to haunt the living and to continue to perform his duties to his living relations. 
2) Second, some aspects of the rites are aimed at equipping the widow with the necessary courage and bravery to cope with the life of self-reliance which the death of the bread winner has exposed her to. (p. 160)

Tasie thus chooses to ignore the fact that these rites were conceived and applied in accordance with the whims of and to the benefit of patriarchy. The stated positive assessment is definitely not meant to benefit the poor widows but to strengthen the hegemonic and imperial patriarchal system. Gichaara (2008, citing Musa W. Dube) claims that this system works as follows:

Gender does not distribute power equally between men and women. Men are constructed as public speakers, thinkers, decision makers and property owners. Women are constructed primarily as domestic beings, who belong to the home or in the kitchen. (p. 192)

Who would believe that African widowhood rites have the purpose of genuinely benefitting widows in such a context? Whilst there is some evidence of the therapeutic value of widowhood rites as evinced above, the problem with many of these cleansing rites is that they do not resonate with human dignity, respect and decorum (see Kotzé et al. 2012:758, 759)

\section{Perceived disadvantages in African widowhood rites and practices}

This section describes the perceived disadvantages of African widowhood rites. Kalu (1989) avers:

The widowhood issue, like that of death is often enmeshed in myth or a mysterious outlay. All attempts are made to make the subject and its processes uncomfortable and painful even in discussions. To those involved in the widowhood process this often involves harrowing and sadistic experiences from the very social support network intended to cushion the traumatic impact of widowhood. (p. 143)

The pain is indeed exacerbated by the fact that it is inflicted by those who are closest to her and whom she has to trust as sources of her comfort. In Women 2000 (Owen 2001:2), one finds the following negative and painful statements by widows from some developing countries:

'We are considered bad omens. We are excluded from all auspicious events' (Lakshmi, Rajasthan, India, Aparajita Newsletter 1995).

'I am accused of being a witch who killed her husband' (Terezinha, Zambezia Province, Mozambique, 1997).

'We have no shelter; my children can no longer go to school' (Ishrat, Bangladesh, 1995).

'We are treated like animals just because we are widows' (Angela, Nigeria, 1999).

'I and my children were kicked out of the house and beaten by the brothers-in-law' (Seodhi, Malawi, 1994).
'As soon as my husband died, they took everything away, even the pots, blanket and sacks of maize' (Renana, Gujerat, India, 1995).

'My husband died of AIDS and slept with many women; I am now dying, but his family blames me for his death' (Isabel, Kenya, 1996).

Although these problems are experienced by widows in many developing countries, I choose to focus on the situation in Africa in this article. The above statements give a clear indication of the extent of marginalisation, accusations of witchcraft, impoverishment, human rights and dignity violations, physical abuse and undue blame for AIDS transmission that widows in developing countries face. My stated focus is the plight of African widows.

Gunga (2009) defines widowhood in very negative terms when he says, citing Ntozi: 'In many societies, widowhood is a process characterised by rituals, forced remarriages, harassment, rejection, loneliness, poverty, loss of status, fear of the future and depression' (see also Sossou 2002:201-209). The widow is definitely not comforted by these widowhood processes. The above view of widowhood rites rather represents them as defeating their claimed purpose, which is therapy.

Mbatha also exposes some problems with which elderly African widows have to contend. She (Mbatha 1984:56) highlights the following problems, namely 'loneliness, isolation, rejection and alienation', which are also experienced by young widows especially when subjected to hostile treatment which is often the case (see also Manyedi et al. 2003:78). Palmore (1987:93) mentions three problems which are stated in question form: How are the functions of the dead spouse to be replaced? Who should inherit the property of the dead spouse? Where should the surviving family live? These problems are, in Africa in particular, exacerbated by widowhood rites that represent the widow as someone who is defiled or has bad luck and who should therefore not mix with people, especially women who still have husbands. The consequences for the widow are also more severe if she is suspected of being a witch who killed or caused the death of her husband. Widowhood in Africa is therefore an extremely difficult and problematic stage in women's lives. In many African contexts, particularly in Limpopo, one of the woes of widowhood is the demand for the daughter-in-law to remain in her husband's home even after his death. It does not matter how negatively she experienced her in-laws and the community. This, I believe, would not be such a problem if staying or leaving were the widow's own choice, but often it is not. Masenya (1998) rightly notes the following:

In my culture, the death of one's husband is not supposed to release the ngwetši (daughter-in-law) to engage in another marriage relationship if she wishes to. As the Northern Sotho proverb goes, Lebitla la mosadi ke bogadi (a woman's grave is at the place/home of her husband), implying that death of a husband is not supposed to separate a woman from her inlaws. Traditionally and even today in some circles, the deceased 
husband's brother is expected to take responsibility for the family of the deceased for purposes of carrying on the dead brother's line. (p. 83)

The above quotation points to coercion by the patriarchal structures and not volition on the part of the widowed woman. Ramphele (1996:99-117) views this aspect of widowhood as constituting an ambiguous situation in which a widow, while mourning the loss of her spouse, is still considered married. Pauw (1990) also points to this practice with the following statement:

A Sotho widow's marriage is not terminated by the death of her husband but has been, as it were, only temporarily interrupted, to be continued after the period of mourning, ideally by an agnate of the late husband. (p. 85)

Another Northern Sotho saying that is capable of instilling guilt in the newly widowed woman's conscience should she contemplate leaving her in-laws' home is lehu ga le hlalwe [death must not be divorced]. It means that leaving the inlaws' home is tantamount to divorcing the deceased husband which is viewed as an ultimate cruelty.

The greatest injustice in this arrangement is the fact that gender inequality is the norm. For example, in the case of a widower, the marriage is terminated by the death of the wife. Even in the case of continuing the marriage through the sororate '... there is less pressure than for the levirate, hence it does not occur very often' (Pauw 1990:85). In other words, there is no coercion in the case of a widower. What reasons are proffered for the widow's forced residence in the in-laws' home? In this regard, Potash (1986; see also Owen 2001:8) states the following as reasons:

Several factors influence that decision, especially ties to children, who must remain in their fathers' communities, and the fact that Luo widows have no rights to return to their natal home. Parents or brothers may refuse to shelter a separated widow. (p. 45)

The motives for forcing the widow to remain at her husband's home may be varied, but in some instances, it is materialism that causes the in-laws to demand that the widow remains in her in-laws' home and marries the husband's brother. Such demands are most likely motivated by greed, especially the in-laws' wish to keep their deceased son or relative's wealth in the home, as in the story below (see also Baloyi 2013:173).

Nkhwashu (2012:1-2) writes under the title Culture shock for rich widow! Reneilwe hides after sex and marriage demands by family. The story reports the following empirical evidence:

- The widow received compensation to the amount of R3.7 million in lieu of her husband's accidental death at work.

- She inherited a penthouse to the amount of R2.5 million in Secunda and a house of R400 000.00 in Giyani.

- Her in-laws forced her to have a sexual relationship with her husband's younger brother to which she reluctantly acceded.

- They later wanted her to marry the husband's younger brother, which she rejected.
- They (the woman's in-laws) then lined up nine men from the family, dressed in suits, for the widow to choose from. This was when she realised how serious the matter was and realised that she had to escape.

- The widow's in-laws swore that she would not be allowed to go to another man with their son's millions.

- They then brought two children that they say were her late husband's, a fact that she refuted as her husband had never told her about them. The family have four children, two of their own and two adopted. Paternity tests are in the process of being carried out.

This is the extent to which some traditional African families may go in order to obtain a share if not everything from the estate of their deceased relative. In this case, because of the widow's assertiveness and proactive steps, they were not able to disinherit her without engaging in a legal process. It is, however, common knowledge that some widows' properties have been confiscated by the families of their deceased husbands.

The following question immediately comes to mind: What would be the purpose of having this rich widow marry the deceased husband's brother whom she did not love? Some known reasons why this is often done are the following:

- to have the brother save the widow from poverty

- to continue his late brother's family on behalf of his late brother.

This widow was, however, in no danger of poverty, and the family already had four children, two of their own and two adopted ones. I therefore contend that greed was probably the motive in this case. Many widows unfortunately fit Sossou's (2002:201-209) description of them as silent victims.

Restrictive and oppressive environments are surely responsible for their quiescence. Tasie (2013) focuses exclusively on the rural Isiokpo people and their psychosocial concerns, which he claims are the aim of most of the terrible and dehumanising widowhood rites he mentions. He ignores the concern for justice, equality, human rights and human dignity that activists against inhuman widowhood practices are raising. Of course, he speaks from the security of his masculinity. Tasie (2013) writes about women within their restrictive environment which prevents them from openly criticising their dominant cultural customs. Chow (1996:186), writing about women's unity in diversity demonstrations, points out: 'In these demonstrations women spoke their minds freely, unbound by cultural boundaries, class cleavages, and political restrictions.' Most traditional contexts are, however, more restrictive and oppressive, denying the people their freedom to speak against and/or act differently from the dictates of the dominant culture.

What is extremely problematic is Tasie's (2013) defence of the obnoxious widowhood rites notwithstanding the stated painful experiences and protests of women - who are 
themselves subjected to these painful and dehumanising practices. It was out of sheer necessity that the Fourth World Conference on Women (FWCW) and its parallel event, the Nongovernmental Organisational Forum held in China in September 1995, focused on themes that aimed at the protection of women and their human rights (Maran 1996:354), the majority of which can also be applied in remedying the oppressive situation of widows. Examples of these include the following:

- the prevention and elimination of all forms of violence against women and girls

- the eradication of poverty based on sustained economic growth, requiring the involvement of women in economic and social development

- the right of all women to control all aspects of their health, in particular their own fertility

- the full enjoyment by women and girl children of all human rights

- ensuring women's equal access to economic resources, including land, credit, science and technology, and vocational training.

These issues were raised by women, some of whom had first-hand experience of the pain that the violation of such rights inflicted on them personally. Exploring the socioeconomic and cultural contexts of African widowhood in a number of societies, Cattel (2003:49-66) found common features amongst women in general, for example women's social, legal and economic status and their dependence, poverty and patriarchal gender relations. There is therefore no justification for Tasie's (2013) negation of the realities of women's experiences in defence of horrific cultural rites applied to widows. Such horrendous treatment as being '... forced to drink the water that their husbands' corpses have been washed in' (Owen 2001:10; Tasie 2013:158) can never be to the widows' advantage or benefit.

Kaori (2007:11-23) maintains the following in this regard:

- Southern and East Africa experience the phenomenon of property grabbing from women as a form of gendered violence against women.

- Widows are especially vulnerable, partly as a result of weakened customary practices and social safety nets that are used to provide support for widowed women and their children.

- Defending their property has cost some women their lives whilst others have lost their shelter and source of livelihood and have become destitute.

- Property grabbing leads to women losing self-esteem with the resultant inability to defend their rights.

Peterman (2012:543-251) explores asset inheritance amongst widows. He uses two data sources: (1) nationally representative demographics and health survey (DHS) data from 15 sub-Saharan African countries and (2) a 13-year longitudinal study from the Kagera region of north-west Tanzania. Results indicate that, across the 15 DHS countries, less than half of widows reported inheriting any assets. The proportion reporting inheriting the majority of assets is lower. Findings from Kagera indicate that the value of inheritance is significant in determining changes in longterm household welfare. It means that many widows are denied their rightful inheritance in sub-Saharan Africa. In view of its significance in household welfare, the denial of inheritance to widows is a serious injustice.

Idialu (2012:6-11) describes the treatment of widows in Africa as inhuman and as geared towards dehumanising the victims. She views such treatment as a painful psychological experience that can affect the individual throughout her lifetime.

\section{Listening to widows' voices}

The study of Manyedi et al. (2003) explores and describes the Batswana widows' experience of widowhood and mourning process. It also explores and describes the Batswana community beliefs about widowhood and the mourning process. I prefer to use categories of experiences presented by Manyedi et al. (2007:78) especially A, B and C of Table 2 on page 75 as these capture experiences that widows have about widowhood practices. I leave out the fourth category, namely D, as it entails the widow's feelings emanating from losing her husband and does not involve widowhood rites and practices.

Experiencefeeling of isolation due to the stigmatisation of widowhood $(A)$ : One widow interviewed for the study indicated the following: 'I must just stay at home, it means I am in prison.' 'I am not supposed to visit any house and I cannot talk to people' (Manyedi et al. 2007:78). The isolation instils a feeling of imprisonment especially as a result of being shunned by their community in the name of cultural beliefs associated with widowhood (Manyedi et al. 2007:78). Rosenblatt and Nkosi (2007:78) point out that ' $[d]$ uring the sitting, a widow cannot leave except to go to the bathroom. She should not even stand ...' In the case of Batswana, the widow must not even cook for herself because of the fear of bad luck, 'sefifi' (Manyedi et al. 2003:78). Whilst this could be helpful to some in providing a feeling of safety from contamination, it removes the widow's freedom of association and her right to community belonging.

The above statement expresses a widow's negative feelings regarding the isolation and stigmatisation as a result of African traditional widowhood rites and practices. This is also confirmed by other researchers such as Rosenblatt and Nkosi (2007:78). Kotzé et al. (2012:744) mention that widows that were interviewed in their study took up shifting and multiple positions regarding loss and widowhood practices. In their view (Kotzé et al. 2012), these positions have the following implications:

[It] can be read as a refusal to be indifferent to multiple losses, although they also question oppressive mourning practices and hold on to the values, intentions, and hopes of caring solidarity. (p. 744) 
Experience of a stressful life due to the customs prescribed by society $(B)$ : There is discrimination in the application of these rites and practices (see Manyedi et al. 2003:78). In the cleansing process, the widow is expected to, amongst others, take herbs in order to neutralise the bad luck (Manyedi et al. 2003:78). This is done, according to the statement of the widow, not because she accepts it but because she wants to go to work. One of the interviewed widows in Manyedi et al.'s (2003:78) study confirms this, saying: 'So they brought somebody who came to cleanse me and give me those traditional herbs, took me to the cross roads because I gave in, wanting to go to work.'

The widows are often suspected of having caused the death of her beloved deceased husband - something that is discriminating against widows. For example, a widow participant in Manyedi et al.'s (2003:28) research asserts: ' ... they have a lot to say and according to our belief the blacks, when the husband dies the wife has contributed, but when the wife dies no, it is normal'.

Experience of support provided by the internal and external support systems $(C)$ : Support, both emotional and material, from the widows' families is valued highly. Other support systems to the widows are friends, church members and neighbours. It seems, however, that the in-laws are not very supportive, according to widows' perceptions. The following statement of one widow confirms the above-mentioned perceptions:

The support you will get it from your own parents, but the inlaws, ooh! Yes, I mean neighbours, friends and church members, they often come to me, they check on me and as we talk I forget. (Manyedi et al. 2003:79)

From the widows' voices above, it is clear that they accept many of the practices because they are under obligation, not because they are pleased with it. They often accept to have the mourning rites and practices applied to them because non-compliance is viewed as disrespect for their deceased husbands, themselves and the community. The fact that they are regarded as carriers and transmitters of bad luck and defilement that are detrimental to the community, compels them to comply unquestioningly with these rites and practices however painful and distressing they experience them.

\section{Widow maltreatment and oppression is inimical to ubuntu philosophy and conduct}

According to literature, 'Ubuntu forms the core of most traditional African cultures. It embraces a spirit of caring and community, harmony and hospitality, respect and responsiveness' (Mangaliso 2001:24). Citing Broodryk, Msila shows a link between these core values and other positive values of '... warmth, empathy, giving, commitment and love' (Msila 2008:69). I view ubuntu as an African golden rule that says that a person is a person because of others. I believe the implication hereof is well articulated in the proverb: 'What is good for the goose is good for the gander.' Battle (1996:102) says the following in this regard, citing Emeritus Archbishop Desmond Tutu's words of wisdom: '... when I dehumanise you, I inexorably dehumanise myself.' According to this insight, it is unthinkable for people who take ubuntu as their point of departure to treat others in impolite, painful and dehumanising ways as believed to be the case with African mourning rites and practices.

Ubuntu '... is further described as the capacity for reciprocity and dignity, humanity and mutuality in the interest of building and maintaining communities with justice and mutual caring' (Bekker 2010:7). How can people who are supposed to be shaped by $u b u n t u$ with its appreciated values as stated above conduct themselves in such an abusive manner towards the vulnerable widows? The painful and disrespectful conduct towards widows is indeed inimical to the compassionate and caring heart of ubuntu. According to Poovan, Du Toit and Engelbrecht (2006; see also Mbigi \& Maree 1995), ubuntu can be described as follows:

... as the capacity in African cultures to express compassion, reciprocity, dignity, humanity and mutuality in the interest of building and maintaining communities with justice and mutual caring. (p. 17)

Some of these mourning rites are potentially life-threatening as observed in the case of the Isiokpo people where widows are forced to drink water in which their husbands' corpses have been washed (Tasie 2013). The widows' right to good health is grossly violated by such deeds. The same is true of the Luo community in Kenya where forced guardianship and cleansing of widows occur through sexual acts by men who are either chosen to act as the widows' guardians or are so-called professional cleansers, including alcohol abusers, sexual perverts and the insane (Ambasa-Shisanya 2007:610). The latter practice undoubtedly exposes all involved in the sexual cleansing act to the risk of HIV infection. Where are the compassion, respect, dignity and solidarity in such practices? Is all the above-mentioned maltreatment of widows the appropriate way for traditional Africans to support widows and help them to survive?

Widows are further marginalised and discriminated against in property ownership. It is certainly for this reason that Owen (2011:618) avers: 'Widows across a wide spectrum of cultures and religions are often among the very poorest of the poor, due to discrimination they experience in matters of inheritance, land and property rights.' They are thus also impoverished. The basic ubuntu values of humanness, caring, sharing, respect and compassion (Msila 2008:69) are grossly violated according to the above accounts of African widowhood practices. This will become clearer when the experiences of some African widows are proffered.

\section{Christian teaching demands intense care for widows}

Erwin (n.d.:3) states that ' $[t]$ he Bible records the high value of widows to God the Father and God the Son in both the Old 
and New Testaments'. The Hebrew Scriptures therefore give a clear command to God's people to not oppress widows and orphans (Zch 7:10) but to take care of them as God does (Dt. 10:17-18). In the New Testament, in the letter of James (1:27), the care of widows is amongst the deeds that are said to constitute pure and genuinely undefiled religion. Actually, the God of Christians has from the time of Israel's inception as God's people declared Himself the defender of widows (Dt $10: 18 ; 24: 17)$. The care of widows therefore became the true measure of justice amongst God's people (see Is 1:17). God's compassion for widows was to become his covenant people's accepted responsibility (Ac 6:1; Ja 1:27). Both testaments warn that any discriminatory and oppressive action against widows and orphans contravenes God's law relating to love.

It is clear from the Bible that God sets Himself as the protector of widows. Erwin (n.d.) further states the following:

The church that takes its biblical responsibility for the care of and support of widows seriously, will, in obedience to our Lord plan, prepare, and implement an ongoing ministry to them after their bereavement. (p. 3)

This biblical teaching should sensitise the Christian church to be compassionate towards widows. It is however a fact that these practices continue even amongst Christians. Rosenblatt and Nkosi (2007:68) point out: 'In Soweto, perhaps 90\% of the community is considered Christian ... but Christianity has not necessarily ended traditional practices for Zulu widows.' The same is true of other areas as well. Many members of African mainline church prove to have imbibed the traditional spirit of ostracising widows instead of embracing them. The three congregations mentioned above serve as a good example in this regard. The fear amongst traditional Africans of the defilement or bad luck that is associated with African widowhood also seems to be strong amongst Christian believers.

Members of this mainline church are therefore equally guilty of discriminatory conduct against widows. I know of a young widow who, after the funeral of her husband, was told not to come to church (a house church) as she would defile the home. She was extremely traumatised by such a discriminatory rule instead of the warm embrace that she had expected. She sought counsel from me, and I arranged with the minister of our other congregation for her to be accommodated there. I also promised her a secure place at the congregation I serve should she not be accepted at that congregation. She has currently taken up membership in that congregation. That was not the only incident of discrimination against newly widowed women still in black mourning clothes. In all of the three congregations that I have served in three Pretoria townships, I have had to intervene to allow widows to attend our Sunday church services without fear. In all incidences, the widows were shunned and made to feel unworthy of entering the sanctuary. The church I serve has not, as an organisation, attempted to correct this situation and usher in a more humane and caring dispensation.

\section{Conclusion and recommendations}

I have critically examined some African widowhood rites and their perceived benefits and detrimental effects. The data analysed have overwhelmingly indicated that the humiliation and pain caused to African widows by these rites far outweigh the benefits. This research has established that African Christians have been influenced by the traditional African widowhood rites that discriminate against and violate widows' human rights to the extent that they also shun these care-seeking vulnerable women and discriminate against them. This oppressive situation cannot be left unchallenged, considering the life-giving values of $u b u n t u$ and the gracious demands of the Christian teaching in respect of the care of widows. African governments and communities (including Christian churches) need to:

- deliberately and visibly prioritise and work towards the implementation of the third Millennium Development Goals (MDGs) concerning the promotion of gender equality and the empowerment of women, and MDG No. 5 concerning the improvement of maternal health

- single out widows' rights for heightened focus to increase widow protection and care

- redefine, reinterpret and be reoriented to true ubuntu values

- continually discuss the plight of widows at all their gatherings with a view to positively influencing and transforming the situation of women and with regard to their ultimate emancipation.

\section{Acknowledgements Competing interests}

The author declares that he has no financial or personal relationships which may have inappropriately influenced him in writing this article.

\section{References}

Ambasa-Shisanya, C.R., 2007, 'Widowhood in the era of HIV/AIDS: A case study of Slaya district, Kenya', Journal of Social Aspects of HIV/AIDS 4(2), 606-615. http:// dx.doi.org/10.1080/17290376.2007.9724882

Baloyi, L. \& Makobe-Rabothata, M., n.d., 'The African conception of death: A cultural implication', viewed 4 September 2014, from http://iaccp.org/sites/default/files/ stellenbosch_pdf/Baloyi.pdf

Baloyi, M.E., 2013, 'Critical reflections on polygamy in the African context', Missionalia 40(3), 164-181.

Battle, M., 1996, 'The Ubuntu theology of Desmond Tutu', in L. Huley, L. Kretzschmar \& L.L. Pato (eds.), Archbishop Tutu: Prophetic witness in South Africa, pp. 93-105, Human \& Rousseau, Cape Town.

Bekker, C.J., 2010, 'Prophet and servant: Locating Robert K. Greenleaf's counterspirituality of servant leadership', Journal of Virtues and Leadership 1(1), 3-14.

Cattel, M.G., 2003, 'African widows: Anthropological and historical perspectives', Journal of Women and Aging 15(2/3), 49-66. http://dx.doi.org/10.1300/ J074v15n02 04

Chow, E.N.L., 1996, 'Making waves, moving mountains: Reflections on Beijing '95 and beyond', Signs 22(1), 185-192. http://dx.doi.org/10.1086/495141

Creswell, J.W., 2003, Research design: Qualitative, quantitative and mixed method approach, 2nd edn., Sage,Thousand Oaks, CA.

Erwin, J.C., (n.d.), 'The theological foundation for soul care of widows, Part I' Reformation Today 1-19, viewed 14 August 2014, from www.reformation-today. org.

Gichaara, J., 2008, 'Women, religio-cultural factors and HIV/AIDS in Africa', Black Theology: An International Journal 6(2), 188-199. http://dx.doi.org/10.1558/ blth2008v6i2.188 
Gunga, S.O., 2009, 'The politics of widowhood and re-marriage among the Luo of Kenya', Thought and Practice: A Journal of Philosophical Association of Kenya (PAK) 1(1), 161-174. (Premier Issue, New Series)

Idialu, E.E., 2012, 'The inhuman treatment of widows in African communities', Current Research Journal of Social Sciences 4(1), 6-11.

Kalu, W.J., 1989, 'Widowhood and its process in contemporary African society: A psycho-social study', Counselling Psychology Quarterly 2(2), 143-152. http:// dx.doi.org/10.1080/09515078908256674

Kaori, I., 2007, 'Gender-based violence and property grabbing in Africa: A denial of women's liberty and security', Gender \& Development 15(1), 11-23. http://dx.doi. org/10.1080/13552070601178823

Kotzé, E., Lishje, L. \& Rajuili-Masilo, N., 2012, “Women ... mourn and men carry on': African women storying mourning practices - A South African example', Deat Studies 36(8), 742-766. http://dx.doi.org/10.1080/07481187.2011.604463

Limann, L.H., 2003, 'Widowhood rites and the rights of women in Africa: The Ugandan experience', LLM dissertation, Faculty of Law, Makerere University.

Makatu, M.S., Wagner, C. \& Ruane, I., 2008, 'Discourse analysis of the perceptions of bereavement and bereavement rituals of TshiVenda speaking women', Journal of Psychology in Africa 18(4), 573-580.

Mangaliso, M.P., 2001, 'Building competitive advantage from Ubuntu: Management lessons from South Africa', The Academy of Management Perspectives 15(3), 23-33.

Manyedi, M.E., Koen, M.P. \& Greeff, M., 2003, 'Experiences of widowhood and beliefs about the mourning process of the Batswana people', Health SA Gesondheid 8(4), 69-87. http://dx.doi.org/10.4102/hsag.v8i4.146

Maran, R., 1996, 'After the Beijing women's conference: What will be done?' Socia Justice 23(1/2), 63-64.

Masango, M.J.S., 2006, 'African spirituality that shapes the concept of Ubuntu', Verbum et Ecclesia 27(3), 930-943. http://dx.doi.org/10.4102/ve.v27i3.195

Masenya, M.J., 1998, 'Ngwetsi (bride): The Naomi-Ruth story from an African-South African woman's perspective', Journal of Feminist Studies in Religion 14(2), 81-90.

Mbatha, M.S., 1984, 'The causes of alienation among African elderly widows in urban areas and proposed social work remedies', MA in Social Work, Department of Social Work, University of South Africa.

Mbigi, L. \& Maree, J., 1995, Ubuntu: The spirit of African transformation management Knowledge Resources, Randburg.
Msila, V., 2008, 'Ubuntu and school leadership', Journal of Education 68, 67-84.

Nkhwashu, G., 2012, 'Culture shock for rich widow! Reneilwe hides after sex and marriage demands by family', Daily Sun, 25 July, pp. 1-2.

Nowye, A., 2005, 'Memory healing and community intervention in grief work in Africa', Australian and New Zealand Journal of Family 26(3), 147-154. http:// dx.doi.org/10.1002/j.1467-8438.2005.tb00662.x

Osmer, R.R., 2008, Practical theology: An introduction, William B Eerdmans, Grand Rapids, MI.

Owen, M., 2001, Widowhood: Invisible women, secluded or excluded, in the Women 2000 report, United Nations, New York, NY.

Owen, M., 2011, 'Widowhood issues in the context of United Nations Security Council Resolution 1325', International Feminist Journal of Politics 13(4), 616-622. http:// dx.doi.org/10.1080/14616742.2011.611667

Palmore, E., 1987, 'Cross-cultural perspectives on widowhood', Journal of CrossCultural Gerontology 2, 93-105. http://dx.doi.org/10.1007/BF00117178

Pauw, B.A., 1990, 'Widows and ritual danger in Sotho and Tswana communities', African Studies 49(2), 75-99. http://dx.doi.org/10.1080/00020189008707728

Peterman, A., 2012, 'Widowhood and asset inheritance in sub-Saharan Africa: Empirical evidence from 15 countries', Development Policy Review 30(5), 543-571. http://dx.doi.org/10.1111/j.1467-7679.2012.00588.x

Poovan, N., Du Toit, M.K. \& Engelbrecht, A.S., 2006, 'The effect of the social values of ubuntu on team effectiveness', South African Journal of Business Management 37(3), 17-27.

Potash, B., 1986, 'Widows in Africa: An introduction', in B. Potash (ed.), Widows in African societies, pp. 1-43, Stanford University Press, Stanford, CA.

Ramphele, M., 1996, 'Political widowhood in South Africa: The embodiment of ambiguity', Daedalus 125(1), 99-117.

Rosenblatt, P.C. \& Nkosi, B.C., 2007, 'South African Zulu widows in a time of poverty and social change', Death Studies 31, 67-85. http://dx.doi. org/10.1080/07481180600995214

Sossou, M-A., 2002, 'Widowhood practices in West Africa: The silent victims', International Journal of Social Welfare 11, 201-209. http://dx.doi. org/10.1111/1468-2397.00217

Tasie, G.I.K., 2013, 'African widowhood rites: A bane or boom for African women', International Journal of Humanities and Social Science 3(1), 155-162. 